Acta vet. scand. $1960,1,221-228$.

From the Department of Bacteriology and Hygiene,

The Veterinary College of Norway, Oslo.

\title{
THE SEROLOGY OF PSEUDOMONAS AERUGINOSA FROM BOVINE UDDER INFECTIONS
}

By

Olav Sandvik.

Bovine udder infections caused by Pseudomonas aeruginosa are dealt with by various authors (Pickens, Welch and Poelma, 1926; Tucker, 1950; Eieland and Rolfsjord, 1950; Schalm and Woods, 1953; Wilson, 1954; Hessen and Jevnaker, 1955).

Pseudomonas aeruginosa does not seem to be a frequent cause of mastitis as compared with other species of microorganisms. This infection, however, is undoubtedly contagious in some herds, sometimes causing mastitis of bad prognosis. Furthermore, latent udder infections with this organism seem to occur more frequently than generally assumed. Since Pseudomonas infections in man are not uncommon (Kietzmann, 1955) the chance of spreading infections from the bovine udder to man should be of interest from a zoonotic point of view. An apparently increasing frequency of Pseudomonas udder infection is by some authors supposed to have taken place in connection with extensive use of antibiotics and certain disinfectants (Wilson, 1954; Lutz et al., 1958; Sandvik and Skulberg, 1958a).

Serological group and type differentiations of Pseudomonas aeruginosa have been reported by several authors mostly regarding strains of human origin (Aoki, 1926; Kanzaki, 1934/35; Christie, 1948; van den Ende, 1952). Agglutination as well as precipitin reactions have been used (Kleinmaier and Müller, 1958). Köhler (1957) reported the agglutination technique to be unsuccessful in his hands, while the precipitin procedure was found to be valuable in classification of his material. Similar results have been reported by others (cit. Habs, 1957). Habs, however, has presented a system for serological grouping of $P$ s. 
aeruginosa based on heat-resistant $\mathrm{O}$-agglutinogens, thus avoiding the influence of the complex heat-labile antigens. The heat-labile antigens were to some extent found to inhibit the heat-resistant antigens, somewhat analogous to the activity of the Salmonella Vi-antigen. The inhibition was neutralized by boiling. This fact was found to be most important in the preparation of antisera. Habs reported that the method was used with success for classification of strains isolated mainly from human sources, and some strains from water samples. Altogether $\mathrm{Habs}$ included 12 different O-groups in this system. Most of the groups were not found to possess common $\mathrm{O}$-antigens, but in some groups common O-antigens were demonstrated in addition to the predominating group-specific antigen. Müller and Kleinmaier (1958), and Kleinmaier, Schreil and Quincke (1959) made further analysis of the O-antigens of Ps. aeruginosa, and Kleinmaier, Schreiner and Graeff (1958) studied the heat-labile antigens of this species.

Because of the enzootic tendency observed in many cases of Pseudomonas udder infections, the present investigations were carried out to make further differentiation of the isolated strains in an attempt to examine the enzootology. Comparisons were therefore also made with strains from various other sources.

\section{MATERIAL AND METHODS}

Strains. The strains were partly isolated at this institute and partly obtained from other laboratories. Of a total number of 116 strains 63 were isolated from bovine udder infections and 13 from milking machines in herds in which Pseudomonas udder infections were diagnosed (table 2). When 2 or more strains from the same quarter are included, the isolations have taken place at more than 14 days intervals, occasionally after treatment with antibiotics. 19 strains were from water samples or milk samples after preincubation, without any connection with udder infections. 19 strains were obtained from various animal sources including fowl, pig, dog, rabbit and cattle.

All strains were found to be typical for the species $P$ s. aeruginosa according to pigmentation and other cultural, morphological and biochemical properties.

Preparation of group-specific antisera. Only strains being stable in normal rabbit serum and $3.5 \% \mathrm{NaCl}$ solution when tested by the slide agglutination test as described below, were 
used for immunization. The strains were cultured on nutrient agar for $20 \mathrm{hrs}$ at $37^{\circ} \mathrm{C}$. The cultures were then harvested suspending the cells from each petri dish in $3-4$ cc physiological saline, after which the suspensions were heated at $100^{\circ} \mathrm{C}$ for $2 \frac{1}{2} \mathrm{hrs}$ according to Habs (1957). Dilutions equal to about $6.10^{9}$ organisms per cc were injected i.v. into rabbits in amounts of 0.5 , 1 , and 1.5 cc at 6 days intervals. The rabbits were generally bled 6 days after the final injection. Sera were prepared in the ordinary way and preserved by the addition of merthiolate to a final concentration of $1: 10000$. For the present investigation, 7 unabsorbed sera were used. Details regarding these sera and the corresponding homologous antigens are given in table 1 . Because of the predominance of the main antigen component, absorption of the additional components was not found to be necessary. These findings are similar to those already described by Habs.

Table 1.

Strains Titres (by the slide agglutination test) :

\begin{tabular}{rlccccccc}
\hline No & Isolated from & $\begin{array}{c}\text { Serum } \\
\text { I }\end{array}$ & $\begin{array}{c}\text { Serum } \\
\text { II }\end{array}$ & $\begin{array}{c}\text { Serum } \\
\text { III }\end{array}$ & $\begin{array}{c}\text { Serum } \\
\text { IV }\end{array}$ & $\begin{array}{c}\text { Serum } \\
\text { V }\end{array}$ & $\begin{array}{c}\text { Serum } \\
\text { VI }\end{array}$ & $\begin{array}{c}\text { Serum } \\
\text { VII }\end{array}$ \\
\hline I & Bovine mastitis & $1: 150$ & - & - & - & - & - & - \\
II & Bovine mastitis & - & $1: 150$ & - & $(1: 10)$ & - & - & - \\
III & Bovine mastitis & - & - & $1: 125$ & $(1: 10)$ & - & - & - \\
IV & Bovine mastitis & - & - & - & $1: 150$ & - & - & - \\
V & Bull semen & - & - & - & - & $1: 125$ & $1: 40$ & - \\
VI & Dog (otitis ext.) & - & - & - & - & $(1: 10)$ & $1: 150$ & $1: 10$ \\
VII & Chicken (coryza) & - & - & - & - & - & - & $1: 400$ \\
\hline
\end{tabular}

— indicates: no agglutination at serum dilution 1:10.

$(1: 10)$ indicates: weak reaction at serum dilution $1: 10$.

The slide agglutination test. The test was carried out mainly according to the description given by Kleinmaier (1957). Spontaneously agglutinating strains were excluded by checking with normal rabbit serum and 3.5\% NaCl solution. The initial serum dilutions were $1: 10$. Strains giving positive reactions at this dilution were tested at dilutions $1: 25,1: 50,1: 75,1: 100,1: 150,1: 200$ etc. until the endpoint was reached.

\section{RESULTS}

No problems regarding mucoid strains as reported by Kleinmaier (1957) were met within this material, and only 4 strains had to be excluded because of spontaneous agglutination. 


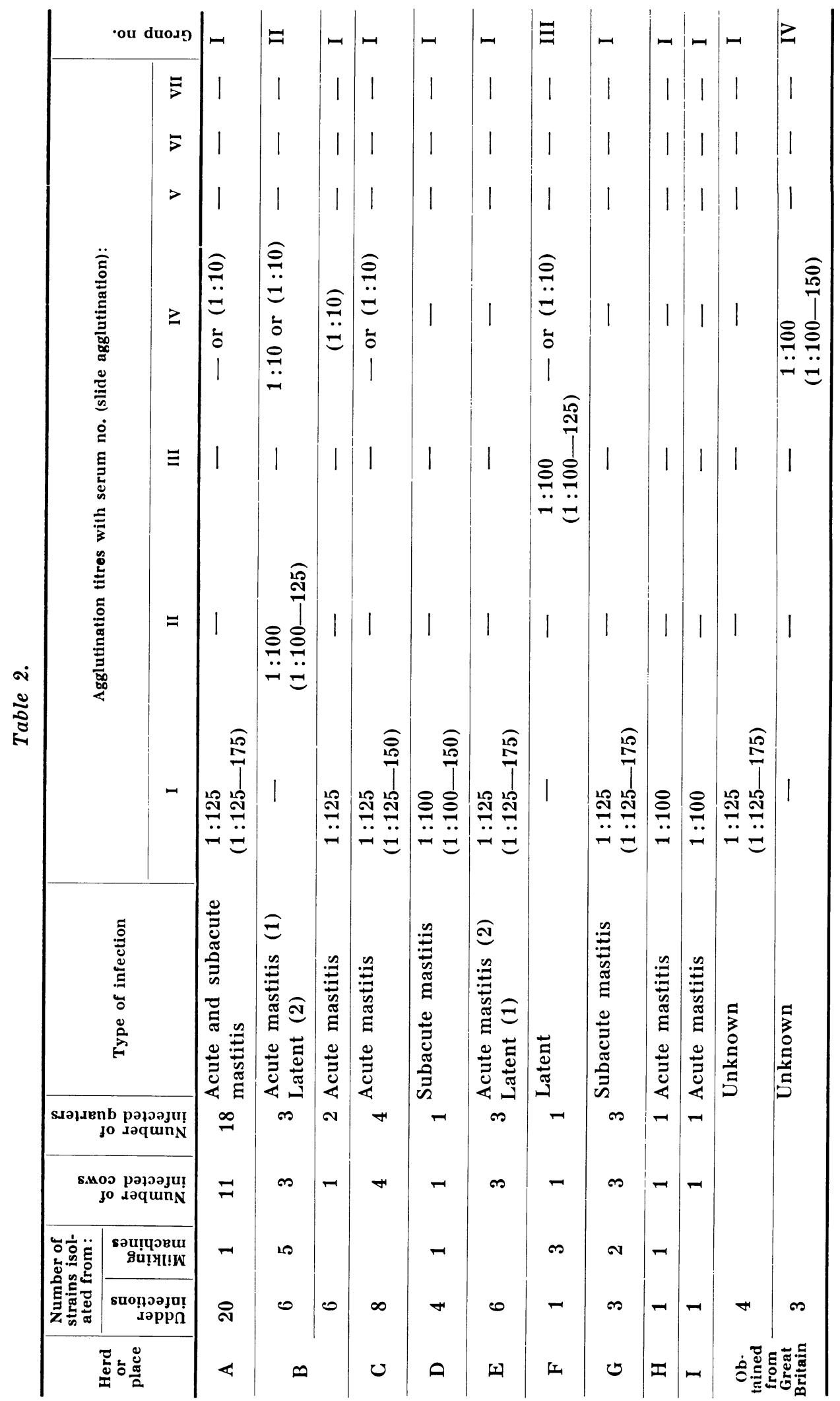


The agglutination titres are shown in table 2 and 3. Spontaneously agglutinating strains are not included in the tables. The group numbers I to VII in the last column in these tables refer to the antigenic relationship to the representative strains I to VII in table 1 respectively. The roman numerals are those of provisional groups established in this laboratory for grouping of Ps. aeruginosa.

Except for 2 strains which showed spontaneous agglutination, all strains isolated from bovine udder infections and milking machines were agglutinated by one or two sera (table 2), showing close antigenic relationship to one of the first 4 representative strains presented in table 1. The strains from various sources (table 3) could in a similar manner in most cases be put into one of the $7 \mathrm{O}$-groups. 2 strains from bull semen exhibited spontaneous agglutination.

Table 3.

\begin{tabular}{|c|c|c|c|c|c|c|c|c|c|}
\hline \multirow{2}{*}{$\begin{array}{l}\text { Isolated } \\
\text { from }\end{array}$} & \multirow{2}{*}{$\begin{array}{c}\text { Number } \\
\text { of cases } \\
\text { (strains) }\end{array}$} & \multicolumn{7}{|c|}{ Titres with serum no. (slide agglutination): } & \multirow{2}{*}{$\begin{array}{c}\text { Group } \\
\text { no. }\end{array}$} \\
\hline & & I & II & III & IV & v & VI & VII & \\
\hline $\begin{array}{l}\text { Water sam- } \\
\text { ples and } \\
\text { preincuba- } \\
\text { ted milk } \\
\text { samples }\end{array}$ & 18 & - & - & - & - & $\begin{array}{c}1: 100 \\
(1: 100 \\
150)\end{array}$ & $\begin{array}{c}1: 25 \\
(1: 25- \\
50)\end{array}$ & - & V \\
\hline Water samp. & 1 & $1: 150$ & 一 & - & - & - & - & - & I \\
\hline $\begin{array}{l}\text { Chicken } \\
\text { (coryza) }\end{array}$ & 3 & - & 一 & 一 & - & - & 一 & $1: 400$ & VII \\
\hline 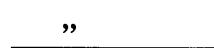 & 1 & - & 一 & $1: 50$ & - & - & - & - & \\
\hline $\begin{array}{l}\text { Calf } \\
\text { (intestinal } \\
\text { infect.) }\end{array}$ & 2 & - & 一 & $1: 25$ & - & - & - & - & \\
\hline$"$ & 1 & - & 一 & $1: 100$ & - & - & 一 & - & III \\
\hline $\begin{array}{l}\text { Bull semen } \\
\text { and prepu- } \\
\text { tial liquid }\end{array}$ & 3 & - & - & $\begin{array}{c}1: 100 \\
(1: 100- \\
125)\end{array}$ & - & - & - & - & III \\
\hline ” & 3 & - & - & - & - & - & - & 一 & \\
\hline Bull semen & 1 & 一 & - & - & - & $1: 125$ & $1: 50$ & 一 & V \\
\hline $\begin{array}{l}\text { Dog (otitis } \\
\text { externa) }\end{array}$ & 1 & - & 一 & 一 & - & $(1: 10)$ & $1: 150$ & $1: 10$ & VI \\
\hline $\begin{array}{l}\text { Swine } \\
\text { (pneumonia) }\end{array}$ & 2 & $1: 125$ & 一 & - & - & 一 & - & - & I \\
\hline
\end{tabular}




\section{DISCUSSION AND CONCLUSION}

The present investigations seem to confirm the value of group differentiation of Pseudomonas aeruginosa according to the method presented by Habs (1957). Thus, the majority of strains investigated has by analysis of the heat-resistant $\mathrm{O}$-agglutinogens been differentiated into $7 \mathrm{O}$-groups. The $\mathrm{O}$-groups have only to small extent exhibited common $\mathrm{O}$-antigens when tested according to the described technique. Regarding the groups IV, (V), VI and VII, however, common $\mathrm{O}$-antigens with other groups occurred in addition to the predominating group-specific antigens. In spite of this, group differentiation by unabsorbed sera was possible because of the extensive predominance of the main antigen.

In the material consisting of strains isolated from mastitis and latent udder infections, 4 O-groups, I, II, III and IV have been demonstrated. The O-group I has by far been the most frequently diagnosed, having been demonstrated in 7 out of 9 infected herds in Norway. 4 out of 7 strains obtained from cases of udder infections in Great Britain also belonged to this group. The remaining 3 groups have only been demonstrated in one herd each. It seems therefore likely that even other O-groups will occur by further serological examinations of Pseudomonas udder infections. More than one $\mathrm{O}$-group in one and the same infected herd have only been observed once (herd B, table 2 ). In that case one cow was found to be infected with group I, $3 \frac{1}{2}$ years after an infection with group II had been demonstrated in 3 cows. On the other hand, one and the same group has been found to remain in the same herd for months, thus demonstrating the serological stability of the groups. The serological relationship between the strains isolated from udder infections and those vegetating in the milking machines on farms where such corresponding studies were made, confirms the conclusions by Sandvik and Skulberg (1958) who consider the milking machines to be a frequent source of Pseudomonas infections, and also being an important vehicle of spreading the infection within infected herds.

The comparatively small number of strains isolated from water samples and preincubated milk samples belonged to $\mathrm{O}$ group $\mathrm{V}$ with the exception of one strain from a water sample which belonged to group I. It seems probable that although most strains of $P s$. aeruginosa present in the water flora may belong 
to more saprophytic groups, also groups with pathogenic properties may exist, and water is considered to be an important source of pathogenic strains of Ps. aeruginosa. This is a great problem in connection with the resistance of Ps. aeruginosa to certain types of disinfectants which may cause a selection of this organism for example in dairy utensils (Sandvik and Skulberg $1958 \mathrm{~b})$.

In some cases members of the O-groups I and III have also been isolated from animal sources other than udder infections.

Further serological studies on the species Ps. aeruginosa will undoubtedly reveal an increasing number of groups and types. Although a complete serological system regarding this species obviously may be very complicated, serological examinations have proved to be valuable in studying the enzootology of isolated outbreaks. As to the strains from bovine udder infections, the differentiation seems to be less complex than for the species as a whole, because of the clear tendency of the majority of strains to belong to group I. A routine and systematic serological classification of strains isolated from udder infections would be of value in establishing the pathogenic properties of the strains and in tracing the ways of spreading infections.

\section{Acknowledgments}

I am greatly indebted to Dr. C. D. Wilson, Veterinary Laboratory, Weybridge; Dr. E. Thal, State Veterinary Institute, Stockholm; and Dr. E. Eieland, Veterinary Public Health Laboratory, Trondheim, all for providing strains of Ps. aeruginosa.

\section{REFERENCES}

Aoki, K.: Zbl. Bakt., I. Abt. Orig. 1926, 96, 186.

Christie, R.: Aust. J. exp. Biol. med. Sci. 1948, 26, 425.

Eieland, E. \& Rolfsjord, L.: Nord. Vet.-Med. 1950, 2, Suppl., 32.

Habs, I.: Z. Hyg. Infekt.-Kr. 1957, 144, 218.

Hessen, L. \& Jevnaker, I.: Medlemsbl. norske Vet. foren. 1955, 6, 165. Kanzaki, K.: Zbl. Bakt., I. Abt. Orig. 1934/35, 133, 89, 94, 99.

Kietzmann, I.: Zbl. Bakt., I. Abt. Ref. 1955, 156, 117.

Kleinmaier, H.: Zbl. Bakt., I. Abt. Orig. 1957/58, 170, 570.

Kleinmaier, H. \& Müller, H.: Zbl. Bakt., I. Abt. Orig. 1958, 172, 54.

Kleinmaier, H., Schreil, W. \& Quincke, G.: Zbl. Bakt., I. Abt. Orig. 1959, 174, 229.

Kleinmaier, H., Schreiner, E. \& Graeff, H.: Z. Immun.-Forsch. 1958, $115,492$.

Köhler, W.: Z. Immun.Forsch. 1957, 114, 282.

Lutz, A., Schaeffer, A. \& Hofferer, M. J.: Ann. Inst. Pasteur, 1958, 95, 49. 
Müller, H. \& Kleinmaier, H.: Z. Hyg. Infekt.-Kr. 1958, 145, 85.

Pickens, E. M., Welch, H. F. \& Poelma, L. J.: Cornell Vet. 1926, 16, 186.

Sandvik, O. \& Skulberg, A.: Forskn. Fors. Landbr. 1958a, 9, 541.

Sandvik, O. \& Skulberg, A.: VIIII Nord. Veterinärmötet, Helsingfors 1958b, Sekt. M., rapport 12.

Schalm, O. W. \& Woods, G. M.: J. Amer. vet. med. Ass. 1953, 122, 462. Tucker, E. W.: Cornell Vet. 1950, 40, 95.

van den Ende, M.: J. Hyg. (Lond.) 1952, 50, 405.

Wilson, C. D.: Vet. Rec. 1954, 66, 775.

\section{SUMMARY}

116 strains of Pseudomonas aeruginosa mainly from animal sources have been serologically classified into 70 -groups. The method used was a slide agglutination test based on heat-resistant $\mathrm{O}$-antigens. The strains isolated from bovine udder infections belonged to one of 4 O-groups with the majority of the strains falling into one particular group. Serological grouping of Ps. aeruginosa has been found valuable in establishing the pathogenic properties of the isolated strains and in studying the reservoir and spread of infections.

\section{ZUSAMMENFASSUNG \\ Die Serologie von Pseudomonas aeruginosa von boviner Euterinfektionen.}

Mit dem Material von 116 Stämmen von Ps. aeruginosa wurde eine serologische Klassifizierung vorgenommen. Die Stämme, die hauptsächlich animalischen Ursprungs waren, wurden in 7 verschiedene O-gruppen differenziert. Die Klassifizierung wurde auf der Grundlage thermostabiler O-Antigene mit Hilfe einer Objektglas-Agglutinationsmethode ausgeführt. Die von Euterinfektionen isolierten Stämme gehörten zu einer von vier O-Gruppen, aber die meisten von denselben liessen sich in eine bestimmte von diesen Gruppen einreihen. Eine serologische Gruppierung von Ps. aeruginosa wird als wertvoll betrachtet, wenn es sich um die Beurteilung der pathogenen Eigenschaften der verschiedenen Stämme und das Studium der Infektionsquelle sowie der Seuchenverbreitung handelt.

\section{SAMMENDRAG}

Pseudomonas aeruginosas serologi ved bovine jurinfeksjoner.

En har foretatt serologisk klassifisering av et materiale av 116 stammer av Ps. aeruginosa. Stammene som hovedsaklig var av animalsk opprinnelse ble differensiert i 7 forskjellige O-grupper. Klassifiseringen ble foretatt på grunnlag av termostabile O-antigener ved hjelp av en objektglass-agglutinasjonsmetode. De stammer som var isolert fra jurinfeksjoner tilhörte én av fire O-grupper, men de aller fleste av dem kunne plaseres i én bestemt av disse grupper. Serologisk gruppering av $P s$. aeruginosa ansees å være verdifull når det gjelder bedömmelse av de forskjellige stammers patogene egenskaper og for a studere smittekilder og smittespredning.

(Received May 16. 1959). 